\title{
FACE-TO-FACE PEER REVIEW AS A TECHNIQUE TO DEVELOP STUDENT'S WRITING SKILL IN PRODUCING NARRATIVE TEXT
}

\author{
Yessi Christina Fentar \\ Email:yessi.fentar@yahoo.co.id
}

\begin{abstract}
This article examined the use of face-to-face peer review in writing class to develop students' writing skill especially in writing a narrative text. The research was categorized as classroom action research and conducted at English Education Department at Tentena Christian University. The subject of the research were 16 students who enrolled writing 3 course. The aim of the research was to develop writing skill of English education department students at Tentena Christian University. Face-to-face peer review is the type of peer review in which the participants take turns to give comments and corrections toward each other writing and discuss it orally to avoid misunderstanding. The research consisted of two cycles where every cycles consisted of five meetings; four meetings for the instructional process and one meeting for the test. The data of the research were collected from observation sheets, field notes, questionnaires and students's test achievement. The result of the research showed that face-to-face peer review was effective in developing the student's skill in writing narrative text.
\end{abstract}

Key words: Face-to-face peer review, developing, writing skill, narrative text.

\section{ABSTRAK}

Artikel ini membahas penggunaan reviu teman sejawat yang berhadapan di kelas menulis untuk mengembangkan keterampilan menulis mahasiswa terutama dalam menulis tek naratif. Penelitian ini digolongkan sebagai penelitian tindakan kelas dan dilaksanakan di Jurusan Pendidikan Bahasa Inggris di Universitas Kristen Tentena. Subjek penelitian ini adalah 16 mahasiswa yang mengambil mata kuliah Writing 3. Tujuan dari penelitian ini adalah untuk mengembangkan keterampilan menulis mahasiswa jurusan pendidikan bahasa Inggris di Universitas Kristen Tentena. Reviu teman sejawat yang berhadapan adalah jenis dari reviu teman sejawat dimana setiap peserta mengambil bagian untuk memberikan komentar dan koreksi terhadap karya tulis yang lainnya dan mendiskusikannya secara oral untuk menghindari kesalapahaman. Penelitian ini terdiri dari dua siklus dimana setiap siklus 
terdiri dari lima pertemuan; empat pertemuan untuk proses belajar mengajar dan satu pertemuan untuk tes. Data dari penelitian ini dikumpulkan dari lembar observasi, catatan lapangan, kuesioner dan hasil tes mahasiswa. Hasil dari penelitian ini menunjukan bahwa reviu teman sejawat secara berhadapan efektif dalam mengembangkan keterampilan mahasiswa dalam menulis teks naratif.

Kata kunci: Reviu teman sejawat secara berhadapan, mengembangkan, keterampilan menulis dan teks naratif.

\section{INTRODUCTION}

Nowadays, review from peers became the trend shifting from the teachercentered approach to student-centered approach. In student-centered approach, the lecturer gives more chance to the students to speak and be active. Besides, in university stage the students should be more independent in doing their tasks. Villamil and Guerrero (1998) believe that peer review fits the learner centered process that expects students to be active learners. They further explain that collaboration with peers contributes to the development of self-regulation that is the capacity for independent problem solving. In face-to-face peer review, students reviewed their peer's writing in class. There is the possibility to discuss the reviews directly with the partner teams. According to Caulk (1994) the peer's feedback is more specific. If it is he compared with teacher's feedback which is sometimes too general, vague, incomprehensible, and authoritative.

Face-to-face peer review takes place in the classroom. Peer review is one source of useful information where students read each other's drafts and give comments on the drafts. It helps the writers to get guidance and feedback on their writing. Students can use those comments and suggestions from their peer to write the 
next draft. Learners are encouraged to comment not only on the strengths of the text but on its weaknesses as well (Ho and Savignon, 2007). By this process, they will be aware of their writing difficulties and see their own progress (Krashen, 1978 cited in Erfanian, 2002).

The face-to-face peer review help the students to gain their knowledge to write better by giving comments and corrections toward their peer writing, get comments and corrections toward their writing and get chance to discuss it with their peer. But face-to-face peer review is not without any limitatioan. First, since learners have to give comments on their peer's writing during peer review, some students might not feel comfortable doing so face to face (Spear, 1987). Second, since they are still developing their own writing proficiency, ESL learners may not trust their peer's response (Paulus, 1999). This might explain why some studies have found that ESL learners prefer teacher feedback to peer response. It may also be the case that peer review is experienced as a threat to the learners' concept of positive face or their positive self-esteem (Brown \& Levinson, 1987).

There some studies has been done dealing with the implementation of face-toface peer review in writing class. Mangelsdorf (1992) explores the question from the perspective of forty advanced ESL writing students who were asked about their experiences with peer reviews. These students came from heterogeneous language background. After all of the students had completed drafting an essay, they traded drafts, read them, and wrote suggestions for revision on review sheets, focusing on content, organization, development, unity and clarity. The students then discussed 
their suggestions with each other. The research showed peer reviews were perceived as a beneficial technique that helped the students revise their papers. The students pinpointed content and organization as the main areas that peer reviews improved. In particular, they emphasized that peer reviews led them to consider different ideas about their topics and helped them to develop and clarify these ideas.

In Moloudi's (2011) research, an attempt is made to investigate face-to-face peer review (FFPR) and online peer review (OLPR) and their effectiveness on Malaysian undergraduates' writing in English at Universiti Putra Malaysia (UPM). Participants included 124 Malaysian undergraduates in the Faculty of Economics and Management. They were grouped into two classes: FFPR and OLPR each with nearly 60 students. The two groups did not differ significantly on any demographic variables. The results of the research were FFPR and OLPR affected the proficiency of Malaysian undergraduates' writing in English significantly and Malaysian undergraduates' found both FFPR and OLPR extremely effective in improving their writing in English.

Based on researcher experiences in the classroom, the second year students of English Education Depertment at Tentena Christian University faced difficulties and problems in writing class. The researcher found that in producing a text especially narrative text, most of the students were difficult in expressing and organizing their ideas, using appropriate vocabulary and mechanic and producing grammatical sentences. In expressing their ideas, the students were difficult to develop their topic. In organizing their ideas, they got confused to arrange their ideas due to the generic 
structure of narrative text. In vocabulary, the students sometimes use inappropriate words in the text. The students also wrote the words like how they pronounced it and rarely used commas when they have to put it in the sentence.

The students also got difficulties when they were dealing with English grammar. They still felt confused with the form of irregular and regular verb. For example when the lecturer asked them to write a sentence about their past activities, some of them wrote 'I go to the market yesterday' or 'I goed to the market yesterday', rather than 'I went to the market yesterday'. In making the past tense sentence, most of the students were confused with the form of regular and irregular verb. They tend to add $-e d$ at the end of the irregular verb, for example they wrote goed rather than went, speaked rather than spoke. Some of the students wrote the present word form in the past tense sentences as example above.

In previous writing class, after conducting their writing the students only got reviews or corrections from their lecturer toward their writing. The researcher found that the reviews or corrections from the lecture were difficult for the students to understand and also too general. Because of the lack of vocabulary of the student, sometimes they got difficult to understand what their lecturer's corrections on their writings were, and some of them were afraid of asking repetition for the explanation. It made the students never learned from the errors they made in their writing. After receiving the papers with discouraging red pen, they just looked at the score, folded it desperately, kept it and never looked at it again. 
From those problems, the researcher was interested in carrying out a classroom action research by employing face-to-face peer review (FFPR). In face-toface peer review, the lecturer gives the students chance to discuss their writing with their partner. The students exchange their writing and give written and oral comments usually based on guidelines given to them.

\section{METHODOLOGY}

This research was conducted by using Classroom Action Research and followed several actions such as planning, acting (implementing the action), observing and reflecting. The researcher conducted the action based on the planning that had been designed about the teaching narrative text by using face-to-face peer review technigue. The research consisted of four meetings in which each meeting had different activities.

The study was conducted in English Education Department. The subjects of this research were 16 students who enrolled writing 3 course.

This study applied some instruments to collect data including: observation sheets, field notes, questionnaires and test. An observation sheet was used to observe and record the lecturer's and the students' performance during the teaching and learning process. Field note was used to record some aspects of the teaching and learning activities in the classroom that might not be covered in the observation sheets. The researcher used questionnaire to get additional information from the students about their progress and responds toward the implementation of face-to-face 
peer review in their writing class. The test was used to get the data dealing with students skill in writing. The researcher asked the students to write at least 150 words of narrative text for the test. Content, organization, grammar, vocabulary and mechanic were the components to assess. Furthermore, the instruments mentioned obove were analyzed by using descriptive statistic analysis. In which both qualitative data and quantitative data were analyzed qualitatively.

This classroom action research was considered successful if it met the criteria; first, $80 \%$ of the total students get least 66,00 of the total score of their writing product. Second, students actively follow the instructional process and the procedure implemented during the implementation of face-to-face peer review.

\section{FINDINGS AND DISCUSSION}

After the students practiced to produce a narrative text in meeting 1 to 4 by implementing the face-to-face peer review, the researcher gave individual test to the students on the meeting 5 . The test was intended to know the students writing skill after giving treatments in four meetings. The students' individual score were presented at table below: 
Table 1. The Result of Students' Test Achievement of Cycle 1

\begin{tabular}{|c|c|c|c|c|c|c|c|c|c|c|}
\hline \multirow[b]{2}{*}{ No. } & \multirow{2}{*}{$\begin{array}{l}\text { Initial } \\
\text { Name }\end{array}$} & \multicolumn{5}{|c|}{ Components of Writing } & \multirow{2}{*}{$\begin{array}{c}\text { Total } \\
\text { Gained } \\
\text { Score }\end{array}$} & \multirow{2}{*}{$\begin{array}{c}\text { Standart } \\
\text { Score }\end{array}$} & \multirow{2}{*}{$\begin{array}{c}\text { Converted } \\
\text { Mark }\end{array}$} & \multirow{2}{*}{ Remark } \\
\hline & & $\mathrm{O}$ & $\mathrm{V}$ & G & $\mathrm{C}$ & M & & & & \\
\hline 1 & ANA & 4 & 3 & 3 & 4 & 4 & 18 & 90 & $\mathrm{~A}$ & Successful \\
\hline 2 & $\mathrm{ADS}$ & 3 & 2 & 1 & 2 & 2 & 10 & 50 & $\mathrm{E}$ & Failed \\
\hline 3 & $\mathrm{CNY}$ & 3 & 3 & 3 & 3 & 3 & 15 & 75 & $\mathrm{C}$ & Successful \\
\hline 4 & DCY & 3 & 3 & 2 & 3 & 3 & 14 & 70 & $\mathrm{C}$ & Successful \\
\hline 5 & DRI & 3 & 3 & 2 & 3 & 3 & 14 & 70 & $\mathrm{C}$ & Successful \\
\hline 6 & DVI & 3 & 3 & 2 & 3 & 3 & 14 & 70 & $\mathrm{C}$ & Successful \\
\hline 7 & FTN & 2 & 2 & 2 & 2 & 2 & 10 & 50 & $\mathrm{E}$ & Failed \\
\hline 8 & ITN & 2 & 1 & 1 & 1 & 2 & 7 & 35 & $\mathrm{E}$ & Failed \\
\hline 9 & NBA & 3 & 3 & 2 & 3 & 3 & 14 & 70 & $\mathrm{C}$ & Successful \\
\hline 10 & PNI & 3 & 3 & 2 & 3 & 3 & 14 & 70 & $\mathrm{C}$ & Successful \\
\hline 11 & RSI & 3 & 3 & 2 & 2 & 3 & 13 & 65 & $\mathrm{D}$ & Failed \\
\hline 12 & SSM & 2 & 2 & 1 & 2 & 2 & 9 & 45 & $\mathrm{E}$ & Failed \\
\hline 13 & TMY & 2 & 2 & 2 & 3 & 2 & 11 & 55 & $\mathrm{D}$ & Failed \\
\hline 14 & VNA & 2 & 2 & 1 & 2 & 2 & 9 & 45 & $\mathrm{E}$ & Failed \\
\hline 15 & YLI & 4 & 3 & 2 & 4 & 3 & 16 & 80 & B & Successful \\
\hline 16 & YLN & 4 & 3 & 3 & 3 & 3 & 16 & 80 & B & Successful \\
\hline \multicolumn{2}{|c|}{ TOTAL } & 46 & 41 & 31 & 43 & 43 & 204 & 1020 & & \\
\hline \multicolumn{2}{|c|}{ MEAN SCORE } & 2,88 & 2,56 & 1,94 & 2,69 & 2,69 & 12,75 & 63,75 & & \\
\hline \multicolumn{2}{|c|}{ FAILED } & \multicolumn{9}{|c|}{ 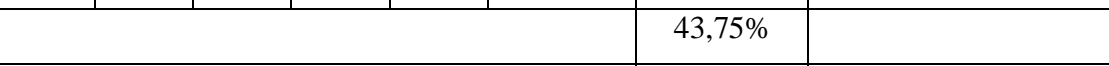 } \\
\hline \multicolumn{2}{|c|}{ SUCCESSFUL } & & & & & & & $56,25 \%$ & & \\
\hline
\end{tabular}

Note:

$$
\begin{array}{llll}
O & =\text { Organization } & C & =\text { Content } \quad G \quad=\text { Grammar } \\
V & =\text { Vocabulary } & M & =\text { Mechanic }
\end{array}
$$

Based on the data above, the researcher analyzed the students' score in aspects of the students' ability in five components of writing; they were organization, vocabulary, grammar, content and mechanic. The researcher has explained that the research would be considered successful if it met two criteria, at least $80 \%$ of the 
students got at least score 66 of the total score of their writing product and the students active involvement on the instructional process.

Based on the data in the table above, the average score of all the students was 63,75 . It was recognized that there were 9 students $(56,25 \%)$ who obtained the score of the assessed components of writing skill that met the criteria of success, 66,00 . On the other hand, the rest 7 students $(43,75)$ did not yet obtain the average score of the five assessed components that met the criteria of success, 66,00.

It was found that the mean score of students' score in Organization was 2,88 in four rating scale. Organization mean score was the highest score from the other components of writing. The highest score in Organization was 4 and the lowest score in Organization was 1 . There were three students who got the highest score 4, eight students who got score 3 , and five students who got score 2 in organization. None of the students got the lowest score 1 in organization. On the other word, only three students who wrote their ideas in correct text organization. However, some of them wrote the sentences almost complete and clear in text organization. Some of them tended to write the sentences unclearly and incompletely. Overall, they were success to organize their ideas into narrative text.

The second assessed component of writing was Vocabulary. It had 2,56 mean score. None of the students got the highest score in vocabulary. There were ten students who got score 3, five students who got score 2 and one student got the lowest score in vocabulary. Although, there were no students got the highest score, 
but the result of the test showed that most of the students can minimize their error in vocabulary.

Grammar was the third assessed components of writing. The mean score of grammar was 1,94 . It was the lowest mean score from the other components of writing. Only three students got score 3, none of the students got the highest score. Nine students got score 2, and 4 students got score 1 . The data showed that most of the students wrote their narrative text ungrammatically. The students' ability in writing grammatical narrative text was very low. Some of them forgot the formula of past tense, some of them were confused to differentiate between regular and irregular verb. So, the grammar of the students' writing product was not appropriate.

The fourth assessed component of writing was content. The mean score of content was 2,69. The highest score was achieved by two students. Eight students got score 3 , five students got score 2 and 1 students got the lowest score. It showed that most of the students idea in their narrative text almost clear. On the other word, only one student's narrative text did not show knowledge of subject.

The last component that the researcher assessed in the research was mechanic. The mechanic covered spelling, punctuation and capitalization. The mean score of mechanic was 2,69. It had the same mean score as content. None of the students got the lowest score and only one student got the highest score in mechanic. There were nine students who got score 3 and the rest six students got score 2 for the mechanic. It meant that one student had good capability in mechanic. Most of them had occasional 
errors of mechanic and only few of them had frequent errors of mechanic but their text could be understood.

The result of the test showed that cycle 1 did not meet the criteria of success.

So, the researcher decided to continue the action to the next cycle.

Table 2. The Result of Students' Test Achievement of Cycle 2

\begin{tabular}{|c|c|c|c|c|c|c|c|c|c|c|}
\hline \multirow{2}{*}{ No. } & \multirow{2}{*}{$\begin{array}{l}\text { Initial } \\
\text { Name }\end{array}$} & \multicolumn{5}{|c|}{ Components of Writing } & \multirow{2}{*}{$\begin{array}{c}\text { Total } \\
\text { Gained } \\
\text { Score }\end{array}$} & \multirow{2}{*}{$\begin{array}{c}\text { Standart } \\
\text { Score }\end{array}$} & \multirow{2}{*}{$\begin{array}{c}\text { Converted } \\
\text { Mark }\end{array}$} & \multirow{2}{*}{ Remark } \\
\hline & & $\mathrm{O}$ & $\mathrm{V}$ & G & $\mathrm{C}$ & M & & & & \\
\hline 1 & ANA & 4 & 4 & 4 & 4 & 4 & 20 & 100 & $\mathrm{~A}$ & Successful \\
\hline 2 & ADS & 3 & 3 & 2 & 3 & 3 & 14 & 70 & $\mathrm{C}$ & Successful \\
\hline 3 & CNY & 4 & 3 & 3 & 4 & 4 & 18 & 90 & $\mathrm{~A}$ & Successful \\
\hline 4 & DCY & 3 & 3 & 3 & 3 & 3 & 15 & 75 & $\mathrm{C}$ & Successful \\
\hline 5 & DRI & 4 & 3 & 3 & 3 & 3 & 16 & 80 & $\mathrm{~B}$ & Successful \\
\hline 6 & DVI & 3 & 3 & 3 & 3 & 3 & 15 & 75 & $\mathrm{C}$ & Successful \\
\hline 7 & FTN & 3 & 3 & 2 & 3 & 3 & 14 & 70 & $\mathrm{C}$ & Successful \\
\hline 8 & ITN & 3 & 2 & 2 & 2 & 2 & 11 & 55 & $\mathrm{D}$ & Failed \\
\hline 9 & $\mathrm{NBA}$ & 3 & 3 & 3 & 3 & 3 & 15 & 75 & $\mathrm{C}$ & Successful \\
\hline 10 & PNI & 3 & 3 & 2 & 3 & 3 & 14 & 70 & $\mathrm{C}$ & Successful \\
\hline 11 & RSI & 4 & 3 & 3 & 3 & 3 & 16 & 80 & B & Successful \\
\hline 12 & SSM & 3 & 3 & 2 & 3 & 3 & 14 & 70 & $\mathrm{C}$ & Successful \\
\hline 13 & TMY & 3 & 2 & 2 & 3 & 2 & 12 & 60 & $\mathrm{D}$ & Failed \\
\hline 14 & VNA & 2 & 2 & 2 & 2 & 2 & 10 & 50 & $\mathrm{E}$ & Failed \\
\hline 15 & YLI & 4 & 3 & 3 & 4 & 3 & 17 & 85 & B & Successful \\
\hline 16 & YLN & 4 & 3 & 3 & 4 & 3 & 17 & 85 & B & Successful \\
\hline \multicolumn{2}{|c|}{ TOTAL } & 53 & 46 & 42 & 50 & 47 & 238 & 1190 & & \\
\hline \multicolumn{2}{|c|}{ MEAN SCORE } & 3,31 & 2,88 & 2,63 & 3,13 & 2,94 & 14,88 & 74,38 & & \\
\hline \multicolumn{2}{|c|}{ FAILED } & & & & & & & \multicolumn{3}{|l|}{$18,75 \%$} \\
\hline \multicolumn{2}{|c|}{ SUCCESSFUL } & & & & & & & $81,25 \%$ & & \\
\hline
\end{tabular}

Note:
$O=$ Organization
$C=$ Content $G=$ Grammar
$V \quad=$ Vocabulary
$M \quad=$ Mechanic 
As in the test of cycle 1, the researcher analyzed the students' writing product based on the aspects of the five assessed components of writing. The components were organization, vocabulary, content, grammar and mechanic. The results of the test were calculated quantitatively. The researcher have explained that the research would be considered successful if at least $80 \%$ of the total students got at least score C or 66 of the total score of their writing product and the students active involvement on the instructional process.

Based on the data presented on the table above, the average score of all the students was 74,38. It was recognized that there were 13 students $(81,25 \%)$ who obtained the score of the assessed components of writing skill that met the criteria of success. On the other hand, only 3 students $(18,75 \%)$ did not yet obtain the average score of the five assessed components that met the criteria of success.

The researcher found that the mean score of the students' individual score in organization was 3,31 in four rating scale. As in cycle 1, the mean score of organization was the highest score from the other components of writing. There was improvement in this component. There were six students who got the highest score 4, nine students who got score 3 and only one student who got score 2 in organization. None of the students got the lowest score in organization. The result showed that the students' skill in organizing the narrative text was increased.

The mean score of vocabulary was 2,88 . Only one student got the highest score. there were 12 students got score 3 and 3 students got score 2 . None of them got 
the lowest score. Although only one student got the highest score, the students' ability in using appropriate vocabulary was developed.

The next component was grammar. This component was the focus on this cycle. It had mean score 2,63 which meant it developed. There were one students got the highest score, eight students got score 3 and 7 students got score 3 in grammar. Although most of them produce ungrammatical sentences but the meaning was still understandable. Same with the previous cycle, this component was the lowest score from other components.

Content was the next assessed component in the test in which it had 3,13 of mean score. The result of the test showed that almost all of the students' successful developing their idea related with their topic. There were 4 students got score 4 , the students ideas were well developed. 10 students got score 3, although their topic had limited development but their ideas related with the topic. Only two students got score 2 and none of them got the lowest score.

The last component was mechanic. The mean score of mechanic was 2,94. There were 2 students got score 4, 11 students got score 3 and 3 students got score 2 . None of them got the lowest score. The main problem that the students faced in mechanic was on spelling and capitalization. All of them used correct punctuation. The students produce incorrect spelling because they tend to write the sentence the way they pronounced it.

The result of students' test achievement in cycle 2 showed that the research met the two criteria of success, the researcher decided to stop the action. It could be 
said that the implementation of face-to-face peer review was successful in solving students' problem in writing especially in writing narrative text.

\section{CONCLUSION}

The purpose of this study was to solve the students' problem in writing skill through face-to-face peer review (FFPR) at English Education Study Program of Tentena Christian University. Based on the findings and discussion of this study, it could be concluded that the students' skill in writing narrative text had developed successfully through the implementation of FFPR. This happened because the students had chance to get their writing being reviewed by their peer. That made the students could minimize their mistakes in their writing. The chance for the students to review their peer's writing gained their knowledge about writing.

Face-to-face peer review could develop the students' writing skill. The students were able to make good improvement on their writing. this happened since the teaching and learning activities were focused on solving the students' problem in producing a text especially narrative text. The activities and environment provided by the researcher during the instructional process attracted the students to participate actively in the classroom. As procedure implemented by face-to-face peer review, the researcher let the students to swap their writing with their peer to get comments and corrections. After commeting and correcting each other writing, they discussed it. This activity let the students to share their ideas and knowledge. It made the students' ability in writing skill developed. 
After conducting the research dealing with face-to-face peer review, the researcher would like to provide some suggestions to the students and the lecturers. For the students, it is hope that they should not be ashamed when their writing were being read and reviewed by other people and when the students were asked to read their friends' writing. So that, they would know their mistakes on their writing and they could help their friends find the mistakes on their writing.

It is recommended for the lecturers especially for those who taught writing to apply face-to-face peer review to solve their students problem in writing. It is also recommended for the lecturers to design interesting teaching and learning activities in order to catch students attention and gain their motivation to learn. 


\section{References}

Brown, P., and Levinson, P. (1987). Politeness: Some Universals of Language Usage. Cambridge: Cambridge University Press.

Caulk, N. 1994. Comparing Teacher and Student responses to Written Work. TESOL Quarterly Vol 28, pg 181-188.

Erfanian, M., 2002. The Effect of Self-Correction Strategy on the Development of Learners' Linguistic Competence. Unpublished Master's Degree Thesis. Allameh Tabatabaei University. Tehran.

Ho, M.C and Savignon, S.J., 2007. Face-to-Face and Computer-Mediated Peer Review in EFL Writing. CALICO Journal, 24 (2), 269 - 290. Retrieved on September $26^{\text {th }} 2014$ from http://Calico.org/memberbrowse.php?action $=$ article $\& i d=645$.

Mangelsdorf, K. 1992. Peer Review in the ESL Composition Classroom: What Do the Students Think? ELT Journal, 46(3), 274-769.

Moloudi, Mehrdad. 2011 Effectiveness of Face-to-Face and onlinePeer Review on Undergraduates' Writing in English. ICT for Language Learning $4^{\text {th }}$ Ed. Retrieved on $26^{\text {th }} 2014$ from www.pixel-online.net/IBL12-82-ABS-MoloudiICT4LL2011.pdf

Paulus, T.M. (1999). The Effect of Peer and Teacher Feedback on Student Writing. Journal of Second Language Writing, Vol 8(3), 265-289.

Spear, K. (1987). Sharing Writing: Peer Response Groups in English Classes.Portsmouth, NH: Heinemann Educational Books, Inc.

Villamil, O., \& Guerrero, M., 1998. Assessing the Impact of Peer Revision on L2 Writing. $\quad$ Retrieved September $26^{\text {th }} \quad 2014$ from http://applij.oxfordjournals.org/cgi/reprint/19/4/491.pdf 